\title{
Serine Hydrolase KIAA1363: Toxicological and Structural Features with Emphasis on Organophosphate Interactions
}

\author{
Daniel K. Nomura ${ }^{\dagger}$, Kathleen A. Durkin $\ddagger$, Kyle P. Chiang§, Gary B. Quistad ${ }^{\dagger}$, Benjamin F. \\ Cravatt $\S$, and John E. Casida ${ }^{\star}, \dagger$ \\ $\dagger$ Environmental Chemistry and Toxicology Laboratory, Department of Environmental Science, Policy and \\ Management, University of California, Berkeley, California 94720-3112, USA \\ $\$$ Molecular Graphics Facility, College of Chemistry, University of California, Berkeley, California \\ 94720-1460, USA
}

$\S$ The Skaggs Institute for Chemical Biology and Departments of Chemistry and Cell Biology, The Scripps Research Institute, La Jolla, California 92037-1000, USA

\begin{abstract}
Serine hydrolase KIAA1363 is highly expressed in invasive cancer cells and is the major protein in mouse brain diethylphosphorylated by and hydrolyzing low levels of chlorpyrifos oxon (CPO) (the activated metabolite of a major insecticide). It is also the primary CPO-hydrolyzing enzyme in spinal cord, kidney, heart, lung, testis and muscle but not liver, a pattern of tissue expression confirmed by fluorophosphonate-rhodamine labeling. KIAA1363-gene deletion using homologous recombination reduces $\mathrm{CPO}$ binding, hydrolysis and metabolism 3- to 29-fold on incubation with brain membranes and homogenates determined with $1 \mathrm{nM} \mathrm{[}{ }^{3} \mathrm{H}$-ethyl] $\mathrm{CPO}$ and the inhibitory potency for residual CPO with butyrylcholinesterase as a biomarker. Studies with knockout mice further show that KIAA1363 partially protects brain $\mathrm{AChE}$ and monoacylglycerol lipase from CPO-induced in vivo inhibition. Surprisingly, mouse brain KIAA1363 and AChE are similar in in vitro sensitivity to seven methyl, ethyl and propyl but not higher alkyl OP insecticides and analogs, prompting structural comparisons of the active sites of KIAA1363 and AChE relative to OP potency and selectivity. Homology modeling based largely on the Archaeoglobus fulgidus esterase crystal structure indicates that KIAA1363 has a catalytic triad of S191, D348 and H378, a GDSAG motif and an oxyanion hole of H113, G114, G115 and G116. Excellent selectivity for KIAA1363 is achieved on OP structure optimization with long alkyl chain substituents suggesting that KIAA1363 has larger acyl and leaving group pockets than those of AChE. KIAA1363 reactivates faster than AChE presumably due to differences in the uncoupling of the catalytic triad His upon phosphorylation. The structural modeling of KIAA1363 helps understand OP structure-activity relationships and the toxicological relevance of this detoxifying enzyme.
\end{abstract}

\section{Keywords}

acetylcholinesterase; chlorpyrifos oxon; detoxification; KIAA1363

\footnotetext{
* To whom correspondence should be addressed., Environmental Chemistry and Toxicology Laboratory, Department of Environmental Science, Policy and Management, 115 Wellman Hall, University of California, Berkeley, California 94720-3112, Tel. 510-642-5424, Fax 510-642-6497, e-mail: ectl@ nature.berkeley.edu.
} 


\section{Introduction}

Serine hydrolase KIAA1363 was first recognized as two glycosylated forms of 45 and $50 \mathrm{kDa}$ by activity-based protein profiling of human cancer cells (1) and mouse brain membranes (2). It is highly expressed in many invasive breast, melanoma and ovarian human cancer cell lines (1) and primary human breast tumors (3) and thus serves as a potential biomarker for diagnosis of cancer. These findings prompted extensive structure-activity studies on trifluoromethyl ketones and related compounds as potent and selective reversible inhibitors of KIAA1363 (2). It is even more sensitive to chlorpyrifos oxon $(\mathrm{CPO})^{1}$ (Figure 1), the activated metabolite of a major insecticide, and many other organophosphates (OPs) and importantly is the principal CPO-binding protein and hydrolase (Figure 2) in mouse brain membranes (4). KIAA1363 is therefore of interest as both an OP-sensitive enzyme and contributor to OP detoxification in brain (4).

The goal of this study is to define the toxicological and structural features of KIAA1363 relative to its interaction with OP inhibitors. The health effects of OP-induced inactivation are deduced from the gene deficiency phenotype. The importance as an OP-detoxifying enzyme is examined by the patterns of expression, $\mathrm{CPO}$ metabolism and protective effects for OP-sensitive targets from inhibition through comparison of KIAA1363 +/+ and -/- mice in vitro and in vivo. OP inhibitors are then optimized for potency towards KIAA1363 relative to acetylcholinesterase (AChE), the primary target of OP poisoning. Finally, the structural features of KIAA1363 are considered by preparing a model, based primarily on the crystal structure of the highly homologous Archaeoglobus fulgidus esterase (AFEST) (5). The OP inhibition and reactivation mechanisms are considered based on docking $\mathrm{CPO}$ and other inhibitors and structural comparisons of KIAA1363 and AChE.

\section{Materials and Methods}

\section{Chemicals}

$\left[{ }^{3} \mathrm{H}\right.$-ethyl]CPO and $\left[{ }^{3} \mathrm{H}\right.$-ethyl]diazoxon (30-40 Ci/mmol) (6), the candidate OP KIAA1363 inhibitors (supplementary material) and $1(3)-\left[{ }^{14} \mathrm{C}\right]$ oleoylglycerol (7) were synthesized in the Berkeley laboratory or obtained from commercial sources. The fluorophosphonate-rhodamine (FP-rhodamine) probe (Figure 1) was from ActivX Biosciences (La Jolla, CA) (8). Insecticides and their analogs were from Sigma (St. Louis, MO) or ChemService (West Chester, PA) and highly purified horse serum butyrylcholinesterase (BChE) was from Sigma.

\section{Toxicology Studies}

Mice, Treatments and Tissue Preparations-Swiss-Webster $+/+$ mice were used for all studies unless specifically stated otherwise. Male albino Swiss-Webster mice (25-30 g) and male and female C57BL/6 mice (15-20 g) were from Harlan Laboratories (Indianapolis, IN). Experimental details for the generation of KIAA1363 knockout (-/-) mice using homologous recombination are available on request from Benjamin Cravatt. KIAA1363-/- and wild-type mice were littermates on a mixed genetic background (129S6/SvEv and C57BL/6) (4), except for the studies comparing $+/+$ and $-/$ - mouse brain homogenates where age and sex-matched C57BL/6 mice were used as the wild-type. Test compounds were administered ip using dimethyl sulfoxide (DMSO) ( $1 \mu \mathrm{L} / \mathrm{g}$ body weight) as the carrier vehicle or DMSO alone was injected as a control. Mouse tissues (fresh or from frozen storage at $-80^{\circ} \mathrm{C}$ ) were homogenized

\footnotetext{
${ }^{1}$ Abbreviations: AADA, arylacetamide deacetylase; AChE, acetylcholinesterase; AFEST, Archaeoglobus fulgidus esterase; AP, acyl pocket; $\mathrm{BChE}$, butyrylcholinesterase; $\mathrm{CPO}$, chlorpyrifos oxon; EG, entry gorge; EPSP synthase, 5-enolpyruvyl shikimate-3-phosphate synthase; DMSO, dimethyl sulfoxide; FP-rhodamine, fluorophosphonate-rhodamine; IC 50, concentration for 50\% inhibition; LGP, leaving group pocket; MAGL, monoacylglycerol lipase; OP, organophosphate; PDB, Protein Data Bank; SDS/PAGE, sodium dodecyl sulfate/polyacrylamide gel electrophoresis
} 
in $100 \mathrm{mM}$ phosphate buffer ( $\mathrm{pH}$ 7.4). Two preparations were used: the homogenate after centrifugation at $1000 \times g$ for $20 \mathrm{~min}$ to remove debris; membranes from centrifugation of the $1000 \times \mathrm{g}$ supernatant at $100,000 \times g$ for $60 \mathrm{~min}$. Membranes were resuspended in phosphate buffer and used directly or held at $-80^{\circ} \mathrm{C}$ until assayed. The Bradford method (9) was used to determine protein.

FP-Rhodamine Labeling-Serine hydrolases were analyzed by the FP-rhodamine procedure $(2,4)$. Briefly, membranes $(50 \mu \mathrm{g}$ protein) and FP-rhodamine $(1 \mu \mathrm{M})$ in $50 \mathrm{mM}$ Tris$\mathrm{HCl}(\mathrm{pH} 8.0)\left(50 \mu \mathrm{L}\right.$ final volume) were incubated for $30 \mathrm{~min}$ at $25^{\circ} \mathrm{C}$. Reactions were quenched with sodium dodecyl sulfate/polyacrylamide gel electrophoresis (SDS/PAGE) loading buffer (reducing) and analyzed by SDS/PAGE and in-gel visualization with a flatbed fluorescence scanner.

$\left[{ }^{3} \mathrm{H}\right] \mathrm{CPO}$ Binding, Hydrolysis and Metabolism-Specific binding was assayed with $\left[{ }^{3} \mathrm{H}\right] \mathrm{CPO}$ by either filtration or SDS/PAGE (4). Thus, membranes or homogenate (200 $\mu \mathrm{g}$ protein) in $100 \mathrm{mM}$ phosphate buffer $(\mathrm{pH} 7.4)(500 \mu \mathrm{L})$ were incubated with $1 \mathrm{nM}\left[{ }^{3} \mathrm{H}\right] \mathrm{CPO}$ for $15 \mathrm{~min}$ at $25^{\circ} \mathrm{C}$ with nonspecific binding (CPO-insensitive sites including the "filter blank") determined by $15 \mathrm{~min}$ preincubation with unlabeled CPO $(100 \mu \mathrm{M})$. Membranes were isolated by filtration through Whatman GF/B filters (presoaked in $0.9 \%$ sodium chloride for $2 \mathrm{~h}$ ) after addition of cold $0.9 \%$ sodium chloride $(2 \mathrm{~mL})$ followed by three washes with fresh cold sodium chloride solution $(2 \mathrm{~mL})$ and scintillation counting. KIAA1363 is the predominant protein labeled by $1 \mathrm{nM}\left[{ }^{3} \mathrm{H}\right] \mathrm{CPO}$ in mouse brain membranes as determined by either SDS/PAGE or filtration under the conditions stated (4), so filtration was therefore used as a convenient assay to measure KIAA1363 binding. AChE and other OP-sensitive proteins were not detectably labeled in mouse brain membranes under these conditions most likely due to their low abundance or low affinity. The concentration of OP for 50\% inhibition $\left(\mathrm{IC}_{50}\right)$ of KIAA1363 binding (determined with $\left[{ }^{3} \mathrm{H}\right] \mathrm{CPO}$ ) involved a 3 -fold dilution series and iterative nonlinear least squares regression. Protein labeling was analyzed by SDS/PAGE and radioassay of gel slices (4).

Partitioning methods were used to determine hydrolysis and metabolism reactions (4). Incubations were carried out as for the binding assays, except for $60 \mathrm{~min}$. Hydrolysis reactions were terminated by addition of potassium carbonate $(200 \mathrm{mM}, 0.83 \mathrm{~mL})$ and extraction with chloroform:methanol:hexane (1.25:1.4:1) $(2.5 \mathrm{~mL})$. Metabolism was analyzed as total CPO reacted, i.e. loss on binding plus hydrolysis. The dpm ligand added was compared to that recovered after incubation using a partitioning procedure. Unmetabolized $\left[{ }^{3} \mathrm{H}\right] \mathrm{CPO}$ was analyzed by partitioning with a mixture of ethyl acetate $(2.0 \mathrm{~mL})$, hexane $(0.8 \mathrm{~mL})$ and water $(0.2 \mathrm{~mL})$. In each case, the upper phase was subjected to scintillation counting.

AChE, BChE and Monoacylglycerol Lipase (MAGL) Activity Assays-AChE and $\mathrm{BChE}$ activities were assayed with acetylthiocholine and butyrylthiocholine, respectively (10-12). $\mathrm{IC}_{50}$ values for OPs with mouse brain $\mathrm{AChE}$ were determined after $15 \mathrm{~min}$ preincubation at $25^{\circ} \mathrm{C}$. BChE was used as a sensitive biomarker for residual $\mathrm{CPO}$ in metabolism studies. Mouse brain membranes (100 $\mu \mathrm{g}$ protein) were incubated with various concentrations of CPO in $100 \mathrm{mM}$ phosphate buffer $(\mathrm{pH} 7.4)(245 \mu \mathrm{L})$ for 60 min before addition of highly purified $\mathrm{BChE}$ as a biomarker $(0.025$ units in $5 \mu \mathrm{L}$ buffer $)$ with incubation for $15 \mathrm{~min}$ to react with residual $\mathrm{CPO}$ before $\mathrm{BChE}$ assay. MAGL activity in brain homogenate (200 $\mu$ g protein) was assayed with $\left[{ }^{14} \mathrm{C}\right]$ oleoylglycerol in $100 \mathrm{mM}$ phosphate buffer $(\mathrm{pH} 7.4)$ $(500 \mu \mathrm{L})(7)$. 


\section{Homology and Structural Analysis}

Homology Analysis and Sequence Alignment-The primary FASTA sequence of mouse KIAA1363 was obtained from the Uniprot Knowledgebase (13) and used for homology analysis with the BLASTp program (14). Sequence alignment was done using CLUSTAL W (15).

Structural Modeling-A structural model of KIAA1363 was built using the X3M program (16) available through a web interface at the Center for Biological Sequence Analysis (BioCentrum-DTU, The Technical University of Denmark, Lyngby, Denmark). This program uses a FASTA sequence in a BLASTp search against a nonredundant database of proteins derived from the Protein Data Bank (PDB) (17) and SWISS-PROT (18). The resulting alignments are refined and the best hit is used as a template for model building. The GeneMine programs, segmod $(19,20)$ and encad $(21,22)$, are employed for gap filling and refinement, respectively. The best homology for a protein with defined crystal structure was with AFEST (PDB ID 1JJI) (5). The structural model generated in this fashion was missing residues 1-60 and 379-408 which were constructed as indicated below.

The transmembrane prediction software, TMPred (23), predicted that at least residues 1-20 form a transmembrane helix. A BLASTp search at NCBI on the PDB database, using just residues 1-69 as input, revealed good alignment with residues 16-64 of 5-enolpyruvyl shikimate-3-phosphate synthase (EPSP synthase) (PDB ID 1Q36) (24). The alignment started at residue 21 of KIAA1363 after the presumed transmembrane segment. The sequence homology with EPSP synthase suggested that residues 21-60 are likely to be alpha helical in character, perhaps joined by short strands or loop regions. This was borne out by secondary structure homology modeling using jpred $(25,26)$ and nnpredict $(27,28)$ (Supporting Information Figure 1). A second structural model of KIAA1363 was generated using the ESyPred3D webserver at the University of Namur, Belgium (29). In that model, good alignment was found with PDB ID 1U4N, which is a M211S/R215L mutant form of the EST2 hydrolase from a thermophilic bacterium (30). In this structure, residues $27-60$ are well defined, as are residues $380-405$. These regions were largely alpha-helical as expected. In this model, however, residues 263-319 were missing and residues 320-325 had an implausible arrangement. Since the KIAA1363 model from X3M was built based on the AFEST crystal structure, good correspondence was expected between the two structures. AFEST has a clearly defined gorge leading to the active site, a gorge that was missing in the originally-generated X3M KIAA363 model. In AFEST, key portions of the gorge are formed by the N-terminal alpha helix along with a C-terminal loop and alpha helix. These regions were missing in the original X3M model generated but were present in the EsyPred3D structure and in other PDB structures with good sequence homology to KIAA1363. These portions are probably crucial leading to a combined homology model, generated with X3M for residues 61-379, EsyPred3D for residues $>379$ and $<61$ and the AFEST structure as an additional guide. Finally, all of the residue sidechains were further minimized using Maestro 7.5 (Schrodinger, L.L.C., Portland, OR.) and MacroModel 9.0 (31) with a water continuum model and the MMFF with a convergence threshold of 0.5. This structure was examined in SwissPDB Viewer (version 3.7) (32) to identify and repair remaining sidechain conflicts (mostly in the C-terminus, far from the active site). This was further minimized using the Gromos force field (33) in the SwissPDB Viewer. The resulting KIAA1363 homology model contained residues 27-396 and had a welldefined active site region.

Modeling of Enzyme-OP Interactions-All small molecules were built using the program Maestro 7.5 and the geometries were optimized using the MMFFs in MacroModel 9.0. These structures were then imported into AutoDock 3.0 (34) and were then docked into KIAA1363 and AChE (1N5M) (35) using the Lamarckian Genetic Algorithm. Several runs were 
performed using cubic grids ranging from 40 to 80 points per side centering on either the Calpha of the His or the O-gamma of the Ser in the catalytic triad. Each run gave 10 hits which were subsequently analyzed for their fit in the catalytic triad region.

\section{Results and Discussion \\ Toxicological Features of KIAA1363}

Phenotype of KIAA1363-Deficient Mice-There was no obvious phenotype associated with the absence of KIAA1363 (4) so no observable long term effects are expected on complete OP-induced inhibition. Some OPs gave partial to complete in vivo KIAA1363 inhibition in brain. Lethargy was apparent in these mice $2 \mathrm{~h}$ after treatment (Table 1) but this was not a diagnostic poisoning sign and the compounds were not KIAA1363-specific inhibitors.

Tissue Expression Profile of KIAA1363-KIAA1363 was expressed in brain, heart, kidney, lung, spinal cord and testis but not liver based on FP-rhodamine labeling and detection as two glycosylated forms at 45 and $50 \mathrm{kDa}$ (Figure 3). A multitude of other serine hydrolases labeled in all tissues by FP-rhodamine remained unchanged on deletion of KIAA1363.

\section{Tissue Specificity for $\left[{ }^{3} \mathrm{H}\right] \mathrm{CPO}$ and $\left[{ }^{3} \mathrm{H}\right]$ Diazoxon Hydrolysis, Binding and Metabolism-Comparison of +/+ and -/- mice established that KIAA1363 was the} predominant hydrolyzing, binding and metabolizing protein for $1 \mathrm{nM}\left[{ }^{3} \mathrm{H}\right] \mathrm{CPO}$ in mouse brain membranes (Figure 4A) and homogenate (Figure 4B) and for $1 \mathrm{nM}\left[{ }^{3} \mathrm{H}\right]$ diazoxon in membranes (Figure 4C). CPO was much more selective than FP-rhodamine for labeling brain KIAA363 compared with other proteins as evident by comparing Figures 3 and 4. KIAA1363 was also the major $1 \mathrm{nM}\left[{ }^{3} \mathrm{H}\right] \mathrm{CPO}$-hydrolyzing enzyme in heart, kidney, lung and testis membranes and spinal cord and muscle homogenates (Table 2). Importantly, no KIAA1363-dependent hydrolysis was found for liver membranes, but there were 45 and $60 \mathrm{kDa}$ proteins labeled (Supporting Information Figure 2). In relation to overall CPO metabolism, KIAA1363 was the principal enzyme in heart membranes and played a significant role in spinal cord and muscle homogenates (Supporting Information Table 1).

KIAA1363 Protects OP-Sensitive Sites-Three types of findings established that KIAA1363 protected OP-sensitive sites from inhibition. The first involved possible protection by KIAA1363 against $1 \mathrm{nM}\left[{ }^{3} \mathrm{H}\right] \mathrm{CPO}$ labeling in vitro found for an $85-\mathrm{kDa}$ protein in brain homogenate (Figures 5A and 5B) and for $60 \mathrm{kDa}$ protein(s) in kidney and lung membranes (Figures $5 \mathrm{C}$ and $\mathrm{D}$ ). The $85-\mathrm{kDa}$ brain protein was possibly BChE based on molecular mass (36), location in the homogenate but not membranes, and bambuterol sensitivity (presumably a selective BChE inhibitor) (37) (Figure 4B) (the bambuterol $\mathrm{IC}_{50}$ for BChE enzymatic activity was $77 \pm 11 \mathrm{nM}$ ). There was about 3-fold more labeling of KIAA1363 compared to 85-kDa protein (Figure 5A and 5B). In the absence of KIAA1363, the 85-kDa protein labeling increased by 2 -fold (Figure $5 \mathrm{~A}$ ), indicating that both of these proteins served as CPO-reactive or metabolizing enzymes. Similar observations applied to KIAA1363 and the CPO-sensitive kidney and lung $60 \mathrm{kDa}$ proteins (Figures 5C and 5D).

The second evidence that KIAA1363 in mouse brain protects against CPO comes from in vitro biomarker experiments. +/+ and -/- brain membranes were incubated with various concentrations of CPO for $60 \mathrm{~min}$ before addition of biomarker BChE to assay residual unreacted CPO. The $\mathrm{IC}_{50}$ of $\mathrm{CPO}$ after incubation with -/- brain membranes was $0.7 \mathrm{nM}$ compared with $+/+$ membranes of $4 \mathrm{nM}$, i.e. a six-fold detoxification by KIAA1363 measured as the decrease in potency (Figure 6). Biomarker BChE inhibition could also be extrapolated to the amount of unmetabolized CPO from $1 \mathrm{nM}$ incubations. Thus, residual CPO gave $71 \%$ inhibition after incubation with $/ /$ - membranes versus $16 \%$ after $+/+$ membranes equivalent 
from a standard CPO inhibition curve to 0.62 and $0.05 \mathrm{nM}$ residual $\mathrm{CPO}$, respectively, i.e. a 12-fold detoxification.

Third, KIAA1363 protection against CPO was also observed in vivo by comparing +/+ and -/mice using three OP-sensitive sites, ie AChE, MAGL [a recently characterized OPtoxicological target (7)], and the $85-\mathrm{kDa}$ labeled protein. Background information for these studies was developed with Swiss-Webster mice (Supporting Information Figure 3). With CPO ip at $2 \mathrm{mg} / \mathrm{kg}$ and assays at $2 \mathrm{~h}$ post-treatment, the $+/+$ mice had less inhibition of AChE than -/- mice (51 \pm 20 versus $74 \pm 16 \%$, respectively) but it was not statistically significant (p-value $=0.19)$ for the number of mice available $(\mathrm{n}=3)$ and no cholinergic poisoning signs were apparent. With CPO at $4 \mathrm{mg} / \mathrm{kg}$ for $24 \mathrm{~h}$, the -/- mice had significantly greater brain AChE inhibition $(75 \pm 3 \%$ ) than their $+/+$ counterparts $(59 \pm 6 \%$ ) (Figure 7 ), although both genotypes had severe cholinergic poisoning at $4 \mathrm{~h}$ with complete recovery at $24 \mathrm{~h}$ (Supporting Information Figure 3). The inhibition by CPO at $4 \mathrm{mg} / \mathrm{kg}$ of both MAGL activity and $85-\mathrm{kDa}$ protein labeling was significantly increased in the -/- compared with the $+/+$ mice (Figure 7). These findings were supported by a model "chemical knockout" experiment in which Swiss Webster mice were treated with the potent and selective KIAA1363 inhibitor $\mathbf{1 1}$ at $10 \mathrm{mg} / \mathrm{kg}$ for $1 \mathrm{~h}$ to completely inhibit KIAA1363 (data not shown). On CPO administration (4 mg/kg ip), these mice still exhibited cholinergic symptoms at $24 \mathrm{~h}$ with increased $\mathrm{AChE}$ inhibition $(84 \pm 3 \%)$ compared to their fully-recovered controls $(69 \pm 4 \%)$, i.e. both the poisoning signs and AChE inhibition were significantly increased by the KIAA1363 inhibitor.

\section{Nonselective and Selective OP Inhibitors for KIAA1363 and AChE}

OP Sensitivity Profiles-Each serine hydrolase has a unique OP sensitivity profile (36). It was therefore surprising to find a similar profile for the first seven OP insecticides and analogs examined in vitro with mouse brain KIAA1363 and AChE $\left(\mathrm{r}^{2}=0.92, \mathrm{n}=7\right)$ (Table 1; Figure 8). Six of the OPs were evaluated with KIAA1363 and AChE in vivo but there was no correlation in the inhibition observed $\left(\mathrm{r}^{2}=0.004, \mathrm{n}=6\right)$ with $\mathrm{AChE}$ generally being much more sensitive (Table 1).

Design of Selective OP Inhibitors-OP inhibitors were selected or designed to potentially disprove the apparent similar or nearly identical in vitro KIAA1363 and AChE sensitivity profiles of compounds 1-7 (Figures 1 and 8). Echothiophate (8) with the quaternary trimethylammonium moiety was found to be highly AChE selective. Compounds $\mathbf{1 - 8}$ are methyl, ethyl or propyl phosphates. Higher alkyl phosphates and phosphonates (9-12) were therefore considered. Two standard fluorophosphonate probes [EOPF (9) and IDFP (10)] were found to have some selectivity for KIAA1363 versus AChE in vitro and good selectivity in vivo (Table 1). This might be due to the long alkyl chains, a hypothesis tested by systematic structure optimization of fluorophosphonates, 4-cyanophenyl phosphonates, 4-nitrophenyl phosphonates and their analogs leading to very high selectivity in vivo for compound $\mathbf{1 1}$ and in vitro for compound 12 (Supporting Information Tables 2 and 3). On an overall basis, the two serine hydrolases had similar sensitivity profiles for OPs with short alkyl chains $\left(\mathrm{C}_{1}, \mathrm{C}_{2}\right.$ and $\mathrm{C}_{3}$ of 1-7) but KIAA1363 was more sensitive to inhibition by longer alkyl chains $\left(\mathrm{C}_{8}\right.$, $\mathrm{C}_{12}$, and $\mathrm{C}_{13}$ of 9-12) (Table 1), implying that there may be common features to the binding sites that allow the shorter alkyl chains to fit both KIAA1363 and AChE while the longer chains are accommodated only by KIAA 1363 .

\section{Structural Features of KIAA1363 Model}

Preparation of KIAA1363 Model Structure-The primary sequence of murine KIAA1363 has high homology with arylacetamide deacetylase (AADA) (E-value $1 \times 10^{-80}$ and identity $43 \%$ ) with good similarity also for AFEST (Table 3) (Supporting Information Figure 4). KIAA1363 and its homologs all have the Ser, His and Asp catalytic triad residues, 
the GDSAG consensus sequence, the HGGG oxyanion hole motif (38) and several other conserved residues. They vary from 310 to 408 amino acids or 35 to $45 \mathrm{kDa}$ (Table 3).

The structural model of KIAA1363 is based primarily on the crystal structure of AFEST (residues 61-379) (5) with the $\mathrm{N}$ - and C-terminus (residues 27-60 and 380-396) constructed using the crystal structure of EST2 hydrolase (30) supplemented by EPSP synthase (24) as an additional guide. The resulting KIAA1363 model contains residues 27-396 with an $\alpha / \beta$ hydrolase fold and a central parallel $\beta$-sheet surrounded by $\alpha$-helices common to serine hydrolases and proteases (Figure 9).

The catalytic S191 is located at the apex of a sharp turn between a $\beta$-strand and an $\alpha$-helix forming the "nucleophilic elbow" with H378 and D348 acting as proton carriers (Figures 9 and 10). S191 sits at the bottom of a large entry gorge (EG) serving as an "acyl pocket" (AP) leading to a side-compartment or "leaving group pocket" (LGP) (Figure 11). H378 is situated in a loop connecting an $\alpha$-helix and $\beta$-strand with its imidazole nitrogen within hydrogen-bonding distance of the nucleophilic S191 hydroxyl hydrogen. The oxyanion hole is mediated by backbone interactions of G114-116 (Figure 10).

OP Interactions with KIAA1363 Model Structure-CPO interactions with KIAA1363 are shown in Figure 11. $O$-Ethyl moieties interact with the EG wall residues or the AP with contacts consisting of the oxyanion hole backbone (G114, G115), L119, A120, Y126, Y127, the nucleophilic elbow residues (D190-A192), Y221, I267, H378, G379, C380 and I382. The $\mathrm{P}=\mathrm{O}$ phosphorus and oxygen also interact with the oxyanion hole backbone, nucleophilic elbow residues, and the catalytic H378 with the phosphorus stabilized further by Y221 and I267. The trichloropyridinyl moiety fits the LGP and interacts with G115 and G116, the nucleophilic elbow residues, Y221, D261, F262, M266, I267, V268, L286, T289, H378 and G379 (specific CPO-residue interactions are further detailed in Supporting Information Table 4).

Compound $\mathbf{1 2}$ docks similarly to CPO relative to the phosphate and aryl substituents (Figures 11 and 12) but has multiple interactions of the $\mathrm{C}_{13}$ alkyl chain with residues lining the gorge wall extending towards the outer lip (Figure 12). These additional residues include G42, A43, V46, I66 and F383. The mechanism for egress of the leaving group (Figure 11) is not known. Reversing the aryl and long alkyl positions of $\mathbf{1 2}$ would facilitate this egress but gives inappropriate positive binding energies. An alternative is another gorge extending from the LGP out of the protein as seen in the AFEST crystal structure (5).

The preference of KIAA1363 for longer alkyl chains was evident not only with OPs such as 12 but also with a series of trifluoromethyl ketones (2). The KIAA1363 active site model is supported by the good fit of the most potent trifluoromethyl ketone ( $\left.\mathrm{IC}_{50} 52 \mathrm{nM}\right), 5$-[[( $1 \mathrm{R}$, 2R)-2-(butoxymethyl)cyclohexyl]methoxy]-1,1,1-trifluoro-2-pentanone (2) (unpublished result).

OP Interactions with AChE-The AChE catalytic triad (S203, H447 and E334) with Ser in a GESAG motif (Table 3) is located at the base of a narrow 18-20 ^ deep EG (Figure 11) (41). The active site is confined by a well-defined AP formed by F295 and 297 and a LGP (often referred to as the "choline binding site") mediated primarily by W86 but also by Y337 and F338 (Figures 11 and 12) (41). Similarities and differences between AChE and KIAA1363 are readily evident upon superimposition of their GXSXG motifs, catalytic triad residues and oxyanion hole backbones (Figures 10, 11 and 12). Many residues in the active site of AChE (A204, F338, F295 and F297) have similar spatial counterparts in the active site of KIAA1363 (e.g. A192, F262, L286 and T289, respectively). In contrast, the KIAA1363 active site is less restrictive due to the dual role of the EG serving as the AP and a larger LGP allowed by L286 and T289 of KIAA1363 replacing the bulkier F295 and F297 of AChE and the absence in 
KIAA1363 of the LGP-confining W86 of AChE (Figure 11). Accordingly, there is a reversal in the spatial functionalities of the AP and LGP of these two enzymes, ie. the KIAA1363 LGP corresponds to the AChE AP and the KIAA1363 AP/EG corresponds to the AChE LGP.

The structural features of AChE and KIAA1363 help explain the similar OP inhibitor profiles seen with short alkyl-chain compounds and selectivity observed for KIAA1363 with long alkylchain analogs. The inhibitor entry angles clearly differ for the two proteins as seen with the surface visualizations (Figure 11). The larger KIAA1363 LGP allows for larger leaving groups to fit deeper and with closer proximity to the catalytic Ser oxygen (Figures 11 and 12). The longer alkyl chains encompass the entire length of the EG as seen with the KIAA1363-selective inhibitor 12. The high affinity of echothiophate for AChE is attributed to hydrophobic interactions of the trimethylammonium moiety with W86 (42) without an equivalent site for KIAA1363.

Faster Reactivation of KIAA1363-KIAA1363 reactivates much faster than AChE. This is consistent with structural features that retard AChE dephosphorylation but are not applicable to KIAA1363 (Scheme 1). Thus, the slow reactivation of AChE is proposed to be due to the uncoupling of the catalytic triad that occurs upon phosphorylation where $\mathrm{H} 447$ moves away from E334 to interact with E202 (described for Torpedo AChE in reference 43). In contrast, the KIAA1363 D190 (spatially equivalent to E202 of AChE) is farther and pointed away from the catalytic H378 (Figure 10) and (although not shown) is stabilized by interactions with Y127 and Y111. As a result, the KIAA1363 catalytic triad presumably remains intact upon phosphorylation, thereby allowing base attack by water on the diethylphosphoryl moiety to form the second tetrahedral intermediate, leading to hydrolysis. In support of this proposal, when AChE E202 is mutated in a computational model to D202 and allowed to optimize to the most favorable rotamer, E202D also points away from H447.

\title{
Conclusions
}

The natural substrate and physiological function of KIAA1363, although unknown, are of considerable interest as an enzyme associated with cancer invasiveness and OP detoxification. The unique toxicological and structural features of KIAA1363 allow it to detoxify some OPs in brain, thereby protecting other sensitive sites both in vitro and in vivo with possible relevance in other tissues. An active site model shows similarities and differences for KIAA1363 compared with $\mathrm{AChE}$ that contribute to the $\mathrm{OP}$ structure-activity relationships and ease of OP hydrolysis. There are many OP-detoxifying enzymes (44) including carboxylesterases of special significance in mice (45). KIAA1363 appears to be particularly important for detoxification in nerve tissue (4) which has several primary and secondary targets of OP poisoning (36).

\section{Supplementary Material}

Refer to Web version on PubMed Central for supplementary material.

\begin{abstract}
Acknowledgements
Our Berkeley laboratory colleagues Shannon Liang, Huiwen Shih and Roger Issa provided advice and assistance. This work was supported by Grants ES008762 (J.E.C.) and CA087660 (B.F.C.) from the National Institutes of Health (NIH) and CHE-0233822 (K.A.D.) from the National Science Foundation (NSF). Its contents are solely the responsibility of the authors and do not necessarily represent the official views of the NIH or NSF.
\end{abstract}




\section{References}

1. Jessani N, Liu Y, Humphrey M, Cravatt BF. Enzyme activity profiles of the secreted and membrane proteome that depict cancer cell invasiveness. Proc Natl Acad Sci U S A 2002;99:10335-10340. [PubMed: 12149457]

2. Leung D, Hardouin C, Boger DL, Cravatt BF. Discovering potent and selective reversible inhibitors of enzymes in complex proteomes. Nat Biotechnol 2003;21:687-691. [PubMed: 12740587]

3. Jessani N, Niessen S, Wei BQ, Nicolau M, Humphrey M, Ji Y, Han W, Noh DY, Yates JR III, Jeffrey SS, Cravatt BF. A streamlined platform for high-content functional proteomics of primary human specimens. Nat Methods 2005;2:691-697. [PubMed: 16118640]

4. Nomura DK, Leung D, Chiang KP, Quistad GB, Cravatt BF, Casida JE. A brain detoxifying enzyme for organophosphorus nerve poisons. Proc Natl Acad Sci U S A 2005;102:6195-6200. [PubMed: 15840715]

5. De Simone G, Menchise V, Manco G, Mandrich L, Sorrentino N, Lang D, Rossi M, Pedone C. The crystal structure of a hyper-thermophilic carboxylesterase from the Archaeon Archaeoglobus fulgidus. J Mol Biol 2001;314:507-518. [PubMed: 11846563]

6. Zhang N, Morimoto H, Williams PG, Casida JE. Synthesis of high specific activity [ethyl-1,2- $\left.{ }^{3} \mathrm{H}\right]-$ labeled chlorpyrifos oxon and diazoxon. J Labelled Cpd Radiopharm 2000;43:1275-1282.

7. Quistad GB, Klintenberg R, Caboni P, Liang SN, Casida JE. Monoacylglycerol lipase inhibition by organophosphorus compounds leads to elevation of brain 2-arachidonoylglycerol and the associated hypomotility in mice. Toxicol Appl Pharmacol 2006;211:78-83. [PubMed: 16310817]

8. Patricelli MP, Giang DK, Stamp LM, Burbaum JJ. Direct visualization of serine hydrolase activities in complex proteomes using fluorescent active site-directed probes. Proteomics 2001;1:1067-1071. [PubMed: 11990500]

9. Bradford MM. A rapid and sensitive method for the quantitation of microgram quantities of protein utilizing the principle of protein-dye binding. Anal Biochem 1976;72:248-254. [PubMed: 942051]

10. Ellman GL, Courtney KD, Andres V Jr, Featherstone RM. A new and rapid colorimetric determination of acetylcholinesterase activity. Biochem Pharmacol 1961;7:88-95. [PubMed: 13726518]

11. Segall Y, Quistad GB, Sparks SE, Casida JE. Major intermediates in organophosphate synthesis $\left(\mathrm{PCl}_{3}, \mathrm{POCl}_{3}, \mathrm{PSCl}_{3}\right.$, and their diethyl esters) are anticholinesterase agents directly or on activation. Chem Res Toxicol 2003;16:350-356. [PubMed: 12641435]

12. Sparks SE, Quistad GB, Casida JE. Organophosphorus pesticide-induced butyrylcholinesterase inhibition and potentiation of succinylcholine toxicity in mice. J Biochem Mol Toxicol 1999;13:113118. [PubMed: 9890196]

13. Apweiler R, Bairoch A, Wu CH, Barker WC, Boeckmann B, Ferro S, Gasteiger E, Huang H, Lopez R, Magrane M, Martin MJ, Natale DA, O'Donovan C, Redaschi N, Yeh LSL. UniProt: the universal protein knowledgebase. Nucleic Acids Res 2004;32:D115-D119. [PubMed: 14681372]

14. Altschul SF, Madden TL, Schäffer AA, Zhang J, Zhang Z, Miller W, Lipman DJ. Gapped BLAST and PSI-BLAST: a new generation of protein database search programs. Nucleic Acids Res 1997;25:3389-3402. [PubMed: 9254694]

15. Thompson JD, Higgins DG, Gibson TJ. CLUSTAL W: improving the sensitivity of progressive multiple sequence alignment through sequence weighting, position-specific gap penalties and weight matrix choice. Nucleic Acids Res 1994;22:4673-4680. [PubMed: 7984417]

16. Lund, O.; Nielsen, M.; Lundegaard, C.; Worning, P. X3M: a Computer Program to Extract 3D Models. Abstract at the CASP5 conference; 2002. p. A102

17. Berman H, Henrick K, Nakamura H. Announcing the worldwide Protein Data Bank. Nat Struct Biol 2003;10:980. [PubMed: 14634627]

18. Boeckmann B, Bairoch A, Apweiler R, Blatter MC, Estreicher A, Gasteiger E, Martin MJ, Michoud K, O'Donovan C, Phan I, Pilbout S, Schneider M. The SWISS-PROT protein knowledgebase and its supplement TrEMBL in 2003. Nucleic Acids Res 2003;31:365-370. [PubMed: 12520024]

19. Levitt M. Accurate modeling of protein conformation by automatic segment matching. J Mol Biol 1992;226:507-533. [PubMed: 1640463]

20. Levitt M. Protein folding by restrained energy minimization and molecular dynamics. J Mol Biol 1983;170:723-764. [PubMed: 6195346] 
21. Levitt M. Molecular dynamics of native protein. I. Computer simulation of trajectories. J Mol Biol 1983;168:595-617. [PubMed: 6193280]

22. Levitt M, Hirshberg M, Sharon R, Daggett V. Potential energy function and parameters for simulations of the molecular dynamics of proteins and nucleic acids in solution. Computer Physics Comm 1995;91:215-231.

23. Hoffman K, Stoffel W. TMbase - A database of membrane spanning protein segments. Biol Chem Hoppe-Seyler 1993;374:166.

24. Eschenburg S, Kabsch W, Healy ML, Schönbrunn E. A new view of the mechanisms of UDP- $N$ acetylglucosamine enolpyruvyl transferase (MurA) and 5-enolpyruvylshikimate-3-phosphate synthase (AroA) derived from X-ray structures of their tetrahedral reaction intermediate states. J Biol Chem 2003;278:49215-49222. [PubMed: 13129913]

25. Cuff JA, Barton GJ. Evaluation and improvement of multiple sequence methods for protein secondary structure prediction. Proteins 1999;34:508-519. [PubMed: 10081963]

26. Cuff JA, Clamp ME, Siddiqui AS, Finlay M, Barton GJ. JPred: a consensus secondary structure prediction server. Bioinformatics 1998;14:892-893. [PubMed: 9927721]

27. McClelland, JL.; Rumelhart, DE. Explorations in Parallel Distributed Processing. 3. MIT Press; Cambridge, MA: 1988. p. 318-362.

28. Kneller DG, Cohen FE, Langridge R. Improvements in protein secondary structure prediction by an enhanced neural network. J Mol Biol 1990;214:171-182. [PubMed: 2370661]

29. Lambert C, Léonard N, De Bolle X, Depiereux E. ESyPred3D: Prediction of proteins 3D structures. Bioinformatics 2002;18:1250-1256. [PubMed: 12217917]

30. De Simone GD, Menchise V, Alterio V, Mandrich L, Rossi M, Manco G, Pedone C. The crystal structure of an EST2 mutant unveils structural insights on the $\mathrm{H}$ group of the carboxylesterase/lipase family. J Mol Biol 2004;343:137-146. [PubMed: 15381425]

31. Mohamadi F, Richards NGJ, Guida WC, Liskamp R, Lipton M, Caufield C, Chang G, Hendrickson T, Still WC. MacroModel - an integrated software system for modeling organic and bioorganic molecules using molecular mechanics. J Comput Chem 1990;11:440-467.

32. Guex N, Peitsch MC. SWISS-MODEL and the Swiss-PdbViewer: an environment for comparative protein modeling. Electrophoresis 1997;18:2714-2723. [PubMed: 9504803]

33. van Gunsteren WF, Berendsen HJC. Computer simulation of molecular dynamics: methodology, applications and perspectives in chemistry. Angew Chem Int Ed Engl 1990;29:992-1023.

34. Morris GM, Goodsell DS, Halliday RS, Huey R, Hart WE, Belew RK, Olson AJ. Automated docking using a Lamarckian genetic algorithm and empirical binding free energy function. J Comput Chem 1998;19:1639-1662.

35. Bourne Y, Taylor P, Radić Z, Marchot P. Structural insights into ligand interactions at the acetylcholinesterase peripheral anionic site. Eur Mol Biol Org J 2003;22:1-12.

36. Casida JE, Quistad GB. Organophosphate toxicology: safety aspects of nonacetylcholinesterase secondary targets. Chem Res Toxicol 2004;17:983-998. [PubMed: 15310231]

37. Tunek A, Svensson LA. Bambuterol, a carbamate ester prodrug of terbutaline, as inhibitor of cholinesterases in human blood. Drug Metab Dispos 1988;16:759-764. [PubMed: 2906603]

38. Hemilä H, Koivula TT, Palva I. Hormone-sensitive lipase is closely related to several bacterial proteins, and distantly related to acetylcholinesterase and lipoprotein lipase: identification of a superfamily of esterases and lipases. Biochim Biophys Acta 1994;1210:249-253. [PubMed: 8280778]

39. Trickett JI, Patel DD, Knight BL, Saggerson ED, Gibbons GF, Pease RJ. Characterization of the rodent genes for arylacetamide deacetylase, a putative microsomal lipase, and evidence for transcriptional regulation. J Biol Chem 2001;276:39522-39532. [PubMed: 11481320]

40. Bourne Y, Taylor P, Bougis PE, Marchot P. Crystal structure of mouse acetylcholinesterase. A peripheral site-occluded loop in a tetrametric assembly. J Biol Chem 1999;274:2963-2970. [PubMed: 9915834]

41. Kovarik Z, Radić Z, Berman HA, Simeon-Rudolf V, Reiner E, Taylor P. Mutant cholinesterases possessing enhanced capacity for reactivation of their phosphonylated conjugates. Biochemistry 2004;43:3222-3229. [PubMed: 15023072] 
42. Ordentlich A, Barak D, Kronman C, Flashner Y, Leitner M, Segall Y, Ariel N, Cohen S, Velan B, Shafferman A. Dissection of the human acetylcholinesterase active center determinants of substrate specificity. J Biol Chem 1993;268:17083-17095. [PubMed: 8349597]

43. Millard CB, Koellner G, Ordentlich A, Shafferman A, Silman I, Sussman JL. Reaction products of acetylcholinesterase and VX reveal a mobile histidine in the catalytic triad. J Am Chem Soc 1999;121:9883-9884.

44. Timchalk, C. Physiologically based pharmacokinetic modeling of organophosphorus and carbamate pesticides. In: Gupta, RC., editor. Toxicology of Organophosphate \& Carbamate Compounds. Elsevier Academic Press; San Diego: 2006. p. 103-126.

45. Maxwell DM, Brecht KM, O'Neill BL. The effect of carboxylesterase inhibition on interspecies differences in soman toxicity. Toxicol Lett 1987;39:35-42. [PubMed: 3672554] 


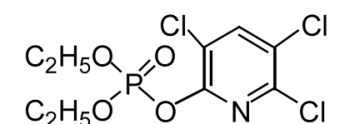<smiles>CCOP(=O)(OCC)Oc1ccc([N+](=O)[O-])cc1</smiles>

1 chlorpyrifos oxon (CPO)

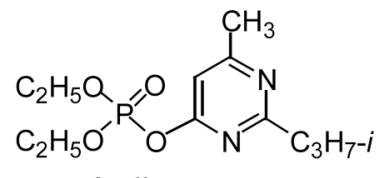

4 diazoxon<smiles>COP(=O)(OC)OC=CCl</smiles>

7 dichlorvos

2 paraoxon

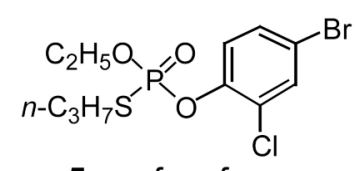

5 profenofos

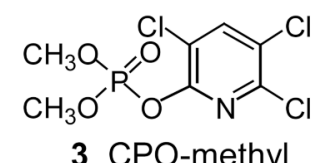

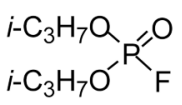

6 DFP

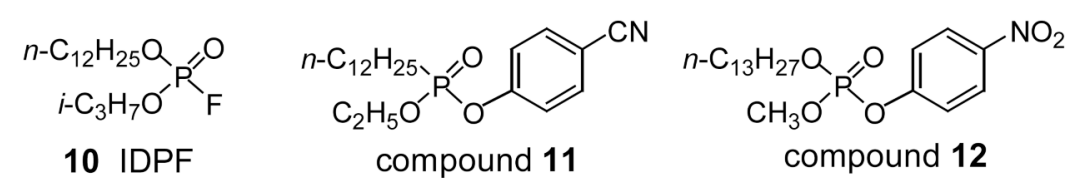

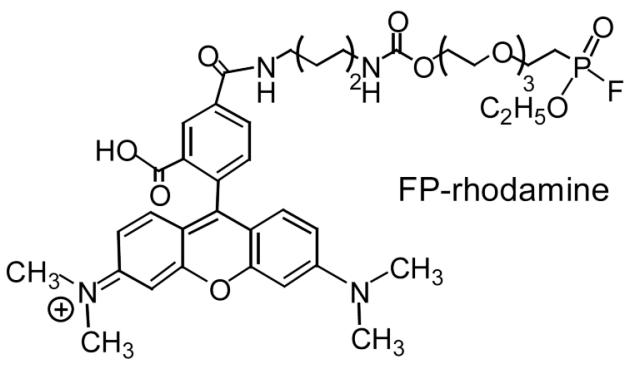

Figure 1. OP compounds studied 


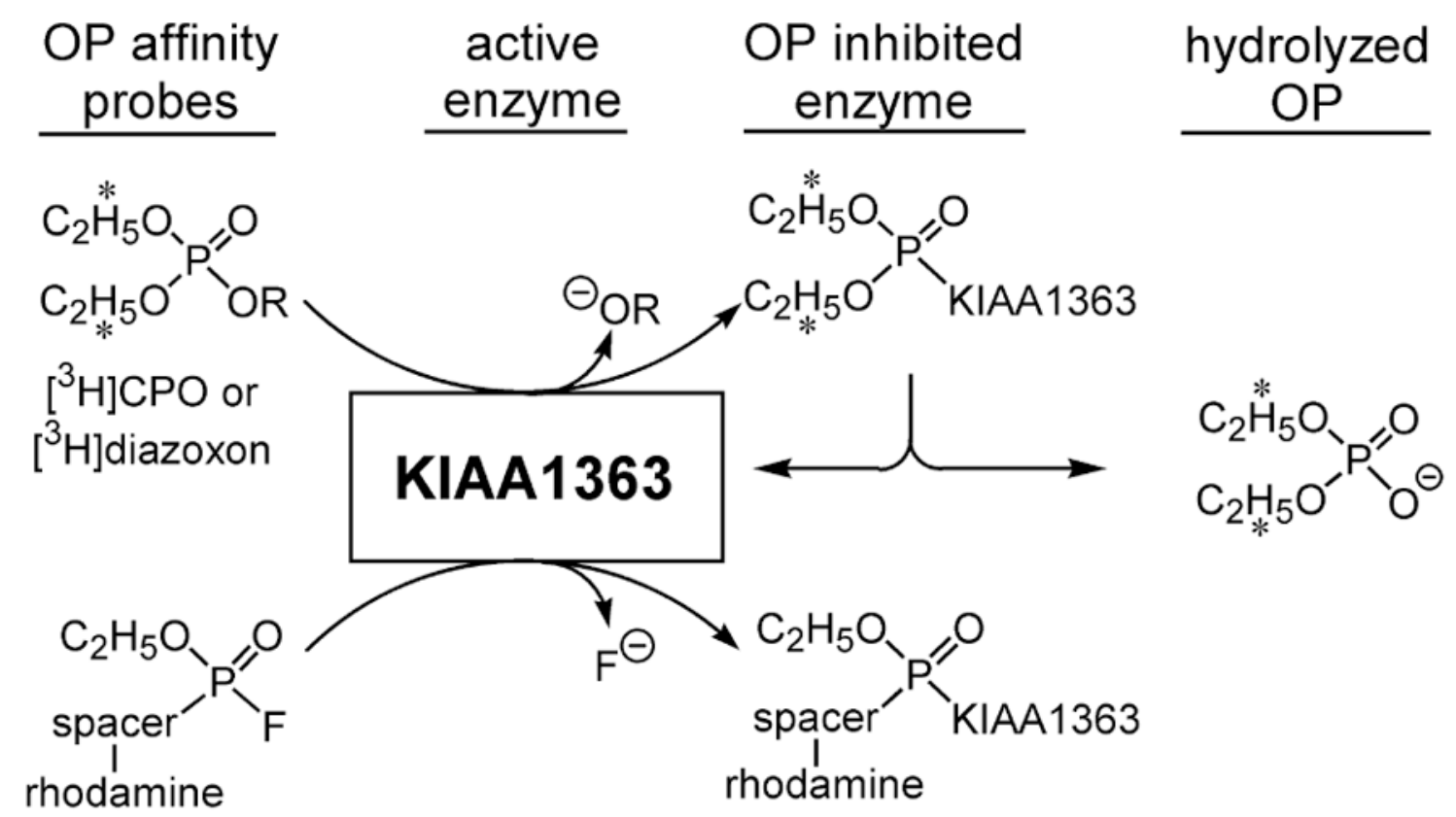

Figure 2.

Reactions of KIAA1363 with $\left[{ }^{3} \mathrm{H}\right] \mathrm{CPO},\left[{ }^{3} \mathrm{H}\right]$ diazoxon and FP-rhodamine. Asterisk designates tritium label. R of CPO is 3,5,6-trichloropyridin-2-yl and R of diazoxon is 2-isoproyl, 6methylpyrimidin-4-yl. $\left[{ }^{3} \mathrm{H}\right] \mathrm{CPO}$ and $\left[{ }^{3} \mathrm{H}\right]$ diazoxon diethylphosphorylate and are hydrolyzed by KIAA1363 whereas FP-rhodamine probably remains phosphorylated. 


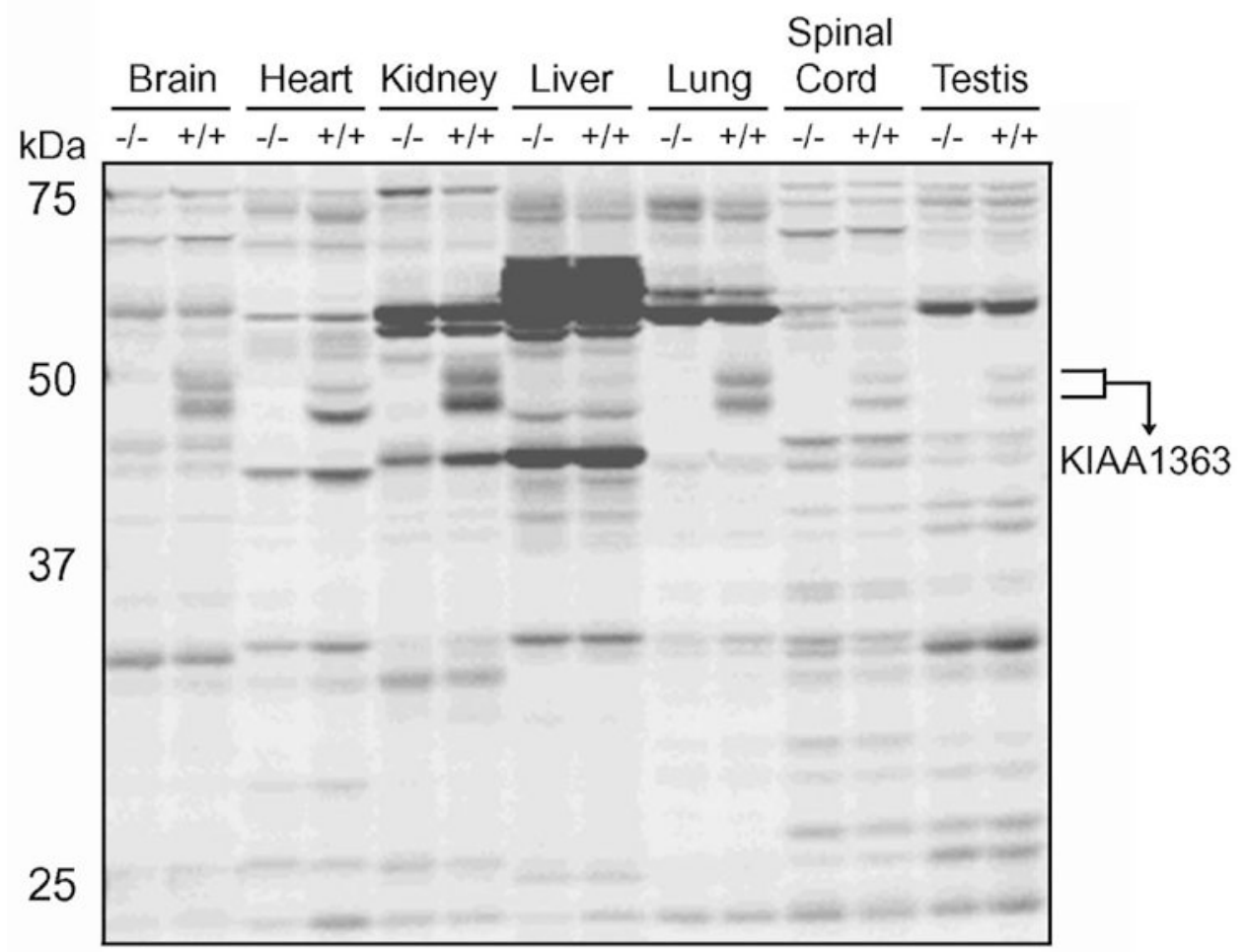

Figure 3.

Tissue expression profiles determined by FP-rhodamine labeling of membrane proteins from KIAA1363 -/- versus +/+ mice. KIAA1363 is expressed in brain, heart, kidney, lung, spinal cord and testis but not liver. Figure is of one representative gel. 

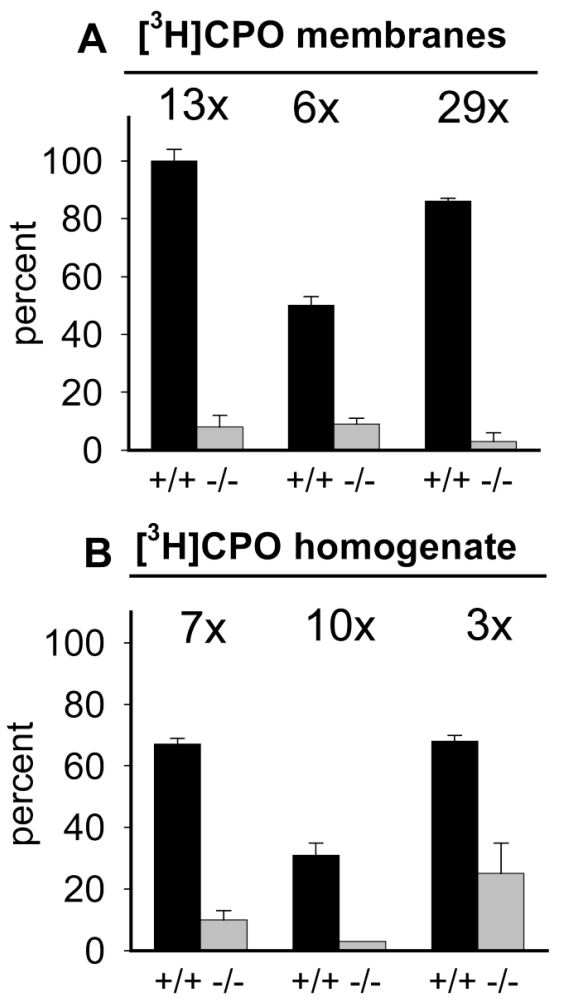

C $\left[{ }^{3} \mathrm{H}\right]$ diazoxon membranes

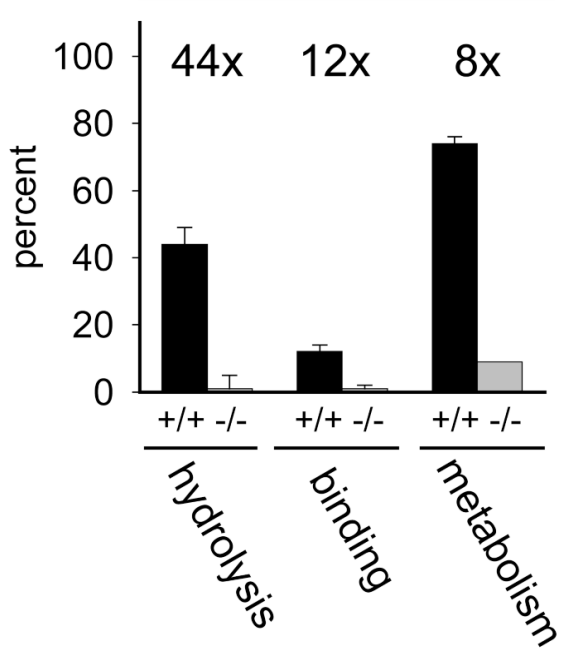

Figure 4.

Effect of KIAA1363 gene deletion on CPO and diazoxon reactions at $1 \mathrm{nM}$ in mouse brain membranes and homogenate. Results are expressed as percent of total ligand added (mean \pm S.D., $\mathrm{n}=3$ ). Incubation times are $15 \mathrm{~min}$ for binding and $60 \mathrm{~min}$ for hydrolysis and metabolism. In membranes (A) and homogenate (B), KIAA1363 is the predominant CPO hydrolyzing, binding and metabolizing enzyme. The same trend also applies with diazoxon and brain membranes $(\mathbf{C})$. The binding ratio is given for $+/+$ divided by $-/-$ mice. 


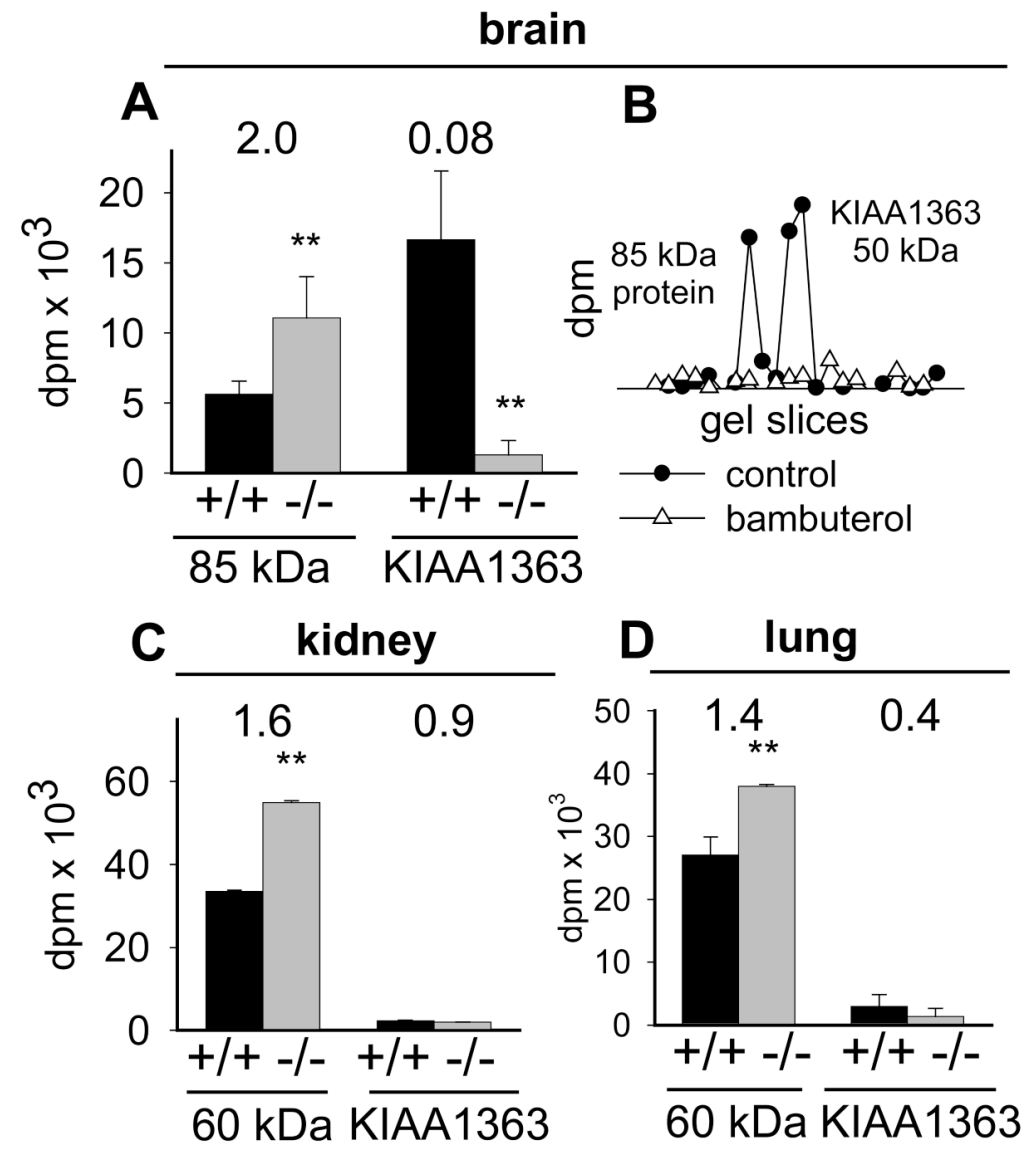

Figure 5.

Effect of KIAA1363 gene deletion on sites sensitive to $\left[{ }^{3} \mathrm{H}\right] \mathrm{CPO}$ at $1 \mathrm{nM}$ in mouse brain homogenate (A and B) and kidney (C) and lung (D) membranes as analyzed by SDS/PAGE. An $85 \mathrm{kDa}$ cytosolic protein in brain (B) and $60 \mathrm{kDa}$ membrane protein(s) in kidney and lung (C and D) have increased $1 \mathrm{nM}\left[{ }^{3} \mathrm{H}\right] \mathrm{CPO}$ labeling in the absence of KIAA1363. Additionally, a $45 \mathrm{kDa}$ protein in kidney membranes and an $85 \mathrm{kDa}$ protein(s) in spinal cord homogenate and heart membranes were unchanged in labeling between genotypes (not shown). Labeling of the $85 \mathrm{kDa}$ protein(s) in brain (B), spinal cord and heart was inhibited by $100 \mu \mathrm{M}$ bambuterol and of KIAA1363 was also sensitive to bambuterol ( $\left.\mathrm{IC}_{50} 6000 \pm 1000 \mathrm{nM}\right)$. The binding ratio is given for -/- divided by $+/+$ mice. Values are mean \pm S.D. ( $n=3$ for $\mathbf{A}$ and $n=6$ for $\mathbf{C}$ and D). $* * \mathrm{p}<0.01$ in unpaired t-test. Although there was relatively little hydrolysis in liver membranes, there was significant labeling of 45 - and $60-\mathrm{kDa}$ proteins both by FP-rhodamine (Figure 2) and $\left[{ }^{3} \mathrm{H}\right] \mathrm{CPO}$ (supplementary materials). 


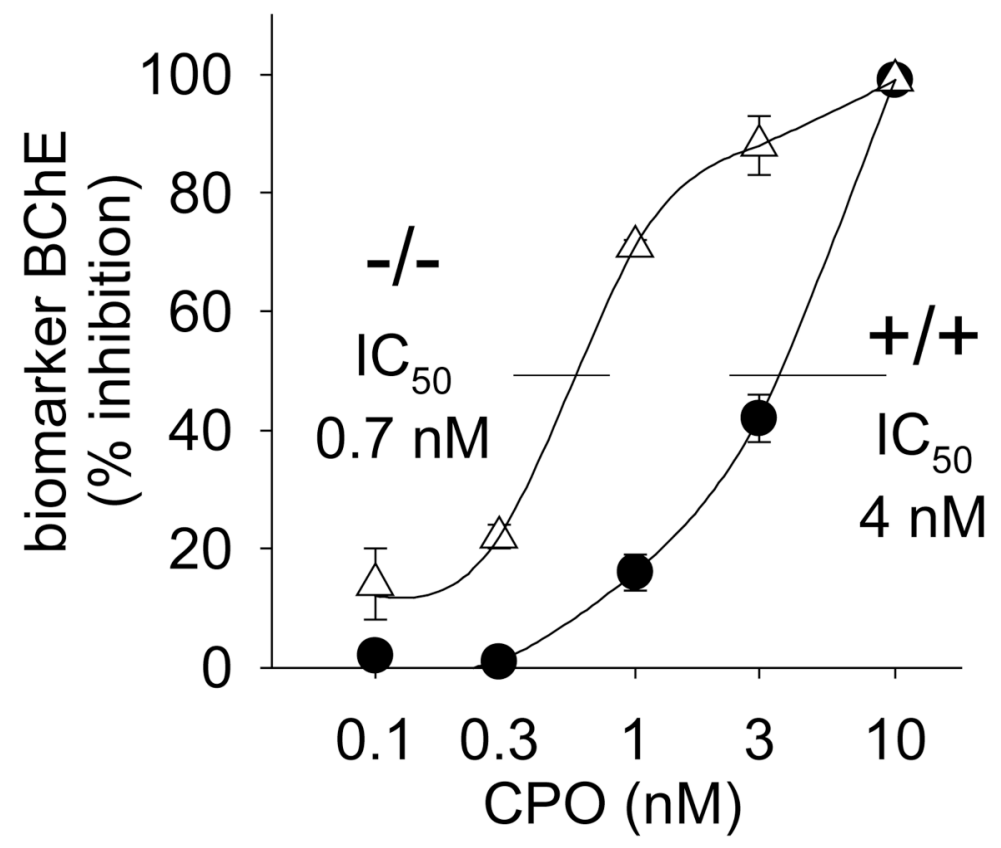

Figure 6.

Detoxification of CPO by brain membranes of KIAA1363 +/+ and -/- mice determined with biomarker BChE (mean \pm S.D., $n=3$ ). Membranes ( $100 \mu$ g protein) were incubated with varying concentrations of $\mathrm{CPO}$ for $60 \mathrm{~min}$ before addition of biomarker BChE for $15 \mathrm{~min}$ to react with residual CPO. 


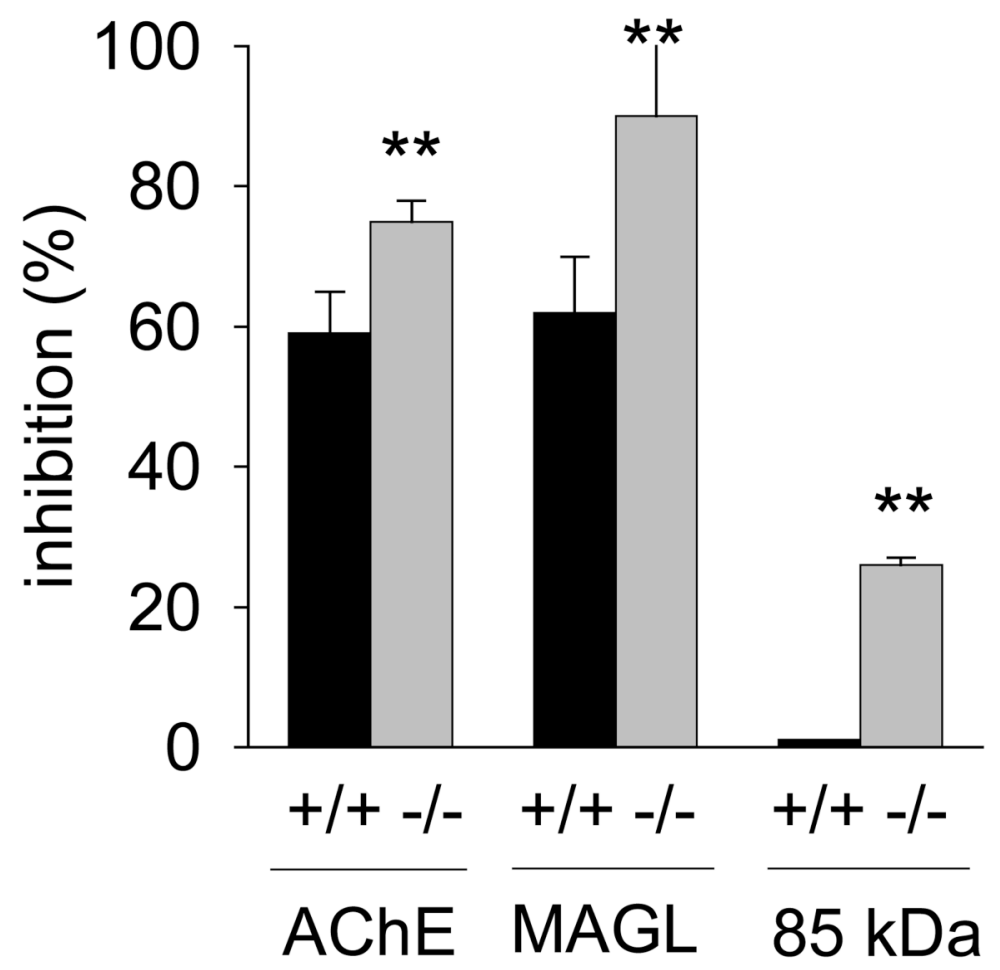

Figure 7.

Effect of KIAA1363 gene deletion on in vivo inhibition of CPO-sensitive proteins $24 \mathrm{~h}$ after a $4 \mathrm{mg} / \mathrm{kg}$ CPO ip dose. AChE (65 kDa) and MAGL (33 kDa) activities and $85 \mathrm{kDa}$-protein labeling were measured in mouse brain homogenate. Values are mean \pm S.D. $(n=4) . * * p<0.01$ in unpaired t-test. Both genotypes showed severe cholinergic poisoning for 4-6 h with full recovery at $24 \mathrm{~h}$. 


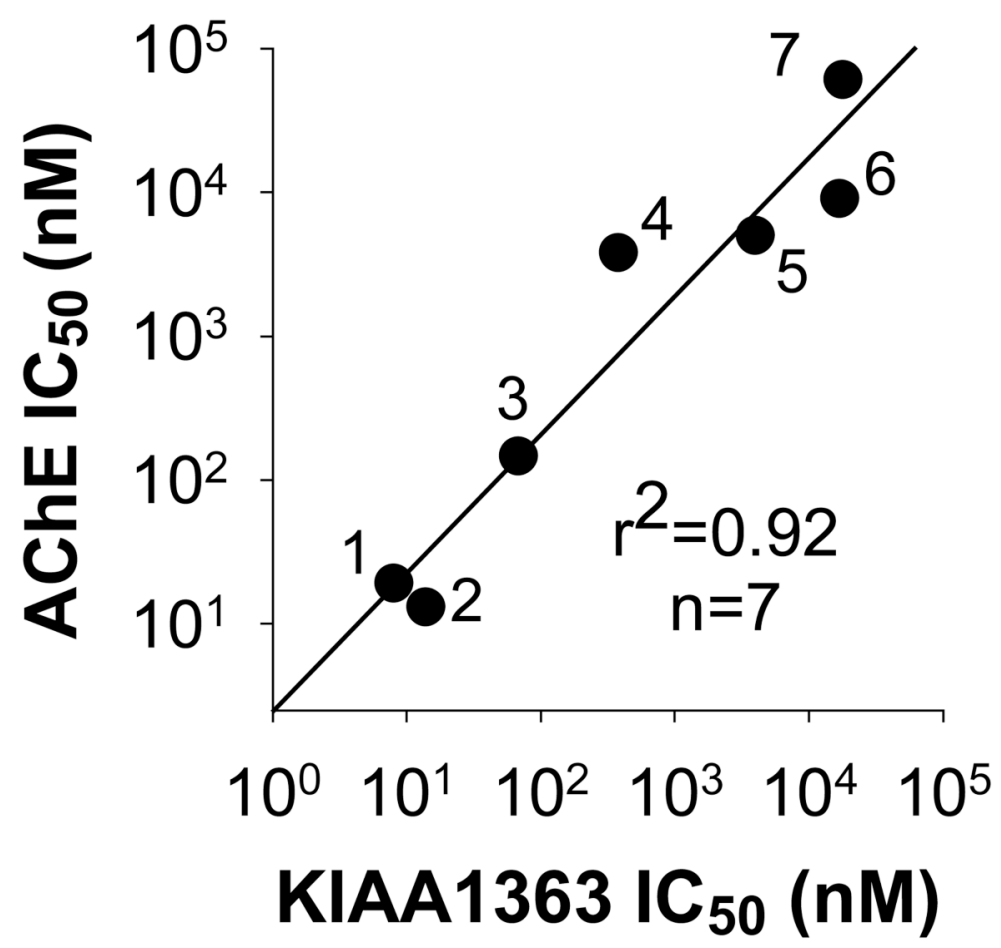

Figure 8.

Correlation of OP sensitivity in vitro of mouse brain KIAA1363 and AChE for seven methyl, ethyl and propyl phosphates. Designations and data are given in Table 1. Using an alternative data set for KIAA1363 with FP-rhodamine assays the $\mathrm{IC}_{50}$ values for compounds 1-7 average 3 -fold lower $\left(r^{2}=0.84, n=7\right)(4)$. 


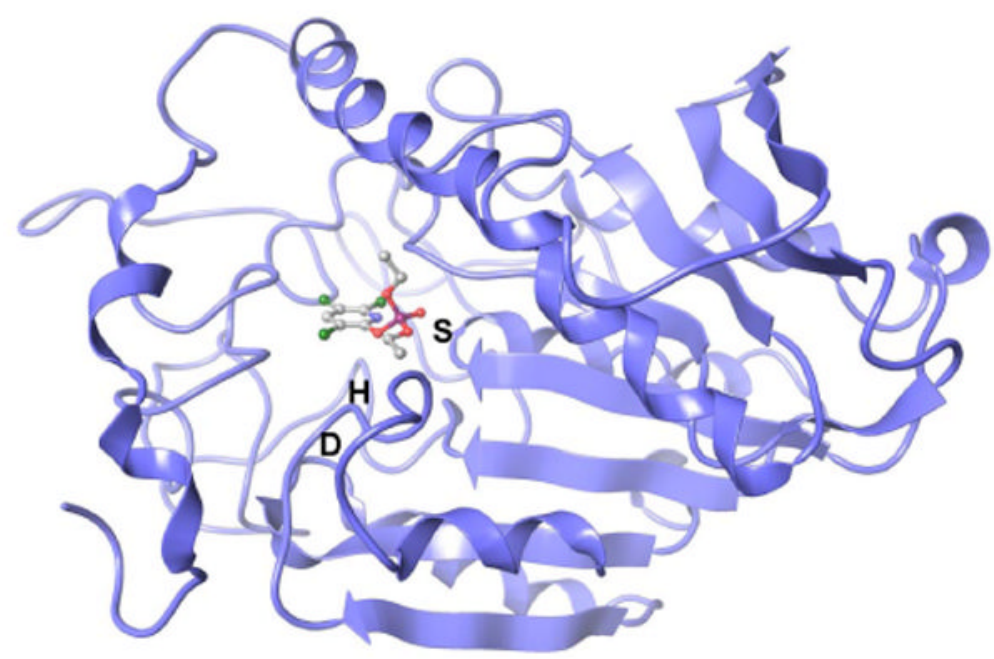

Figure 9.

Homology model of KIAA1363 residues 27-396 showing position of CPO and the catalytic triad (S191, H378 and D348). 


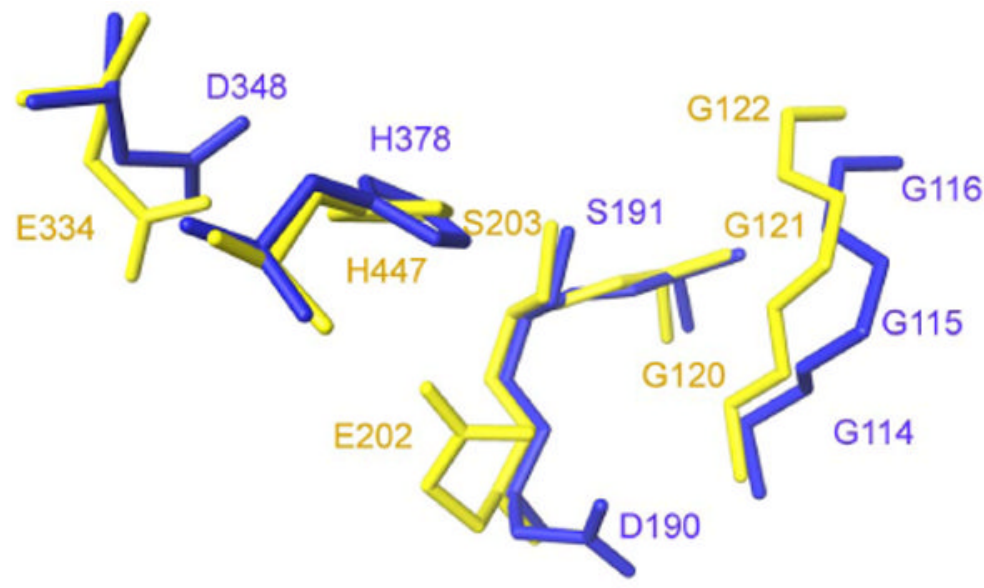

Figure 10.

Superimposition of catalytic triads of KIAA1363 (S191, H378, D348) and AChE (S203, H447, E334) with different positioning of KIAA1363 D190 and AChE E202. Oxyanion hole residues also align well between KIAA1363 (G114, G115, G116) and AChE (G120, G121, G122). KIAA1363 is shown in blue and AChE in yellow (with orange letters). 


\section{KIAA1363}
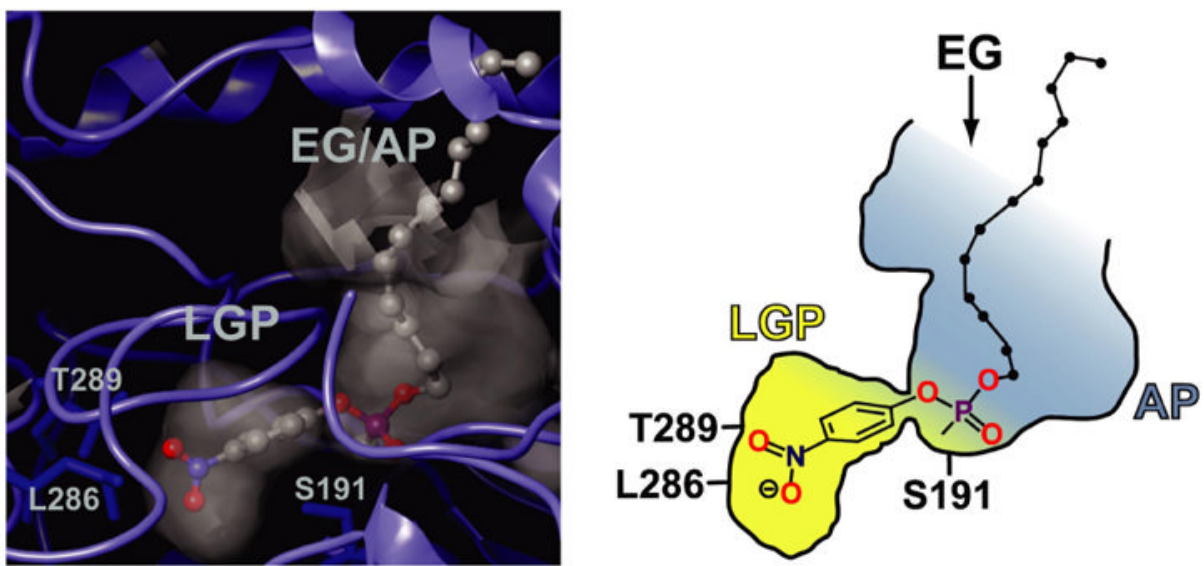

\section{AChE}
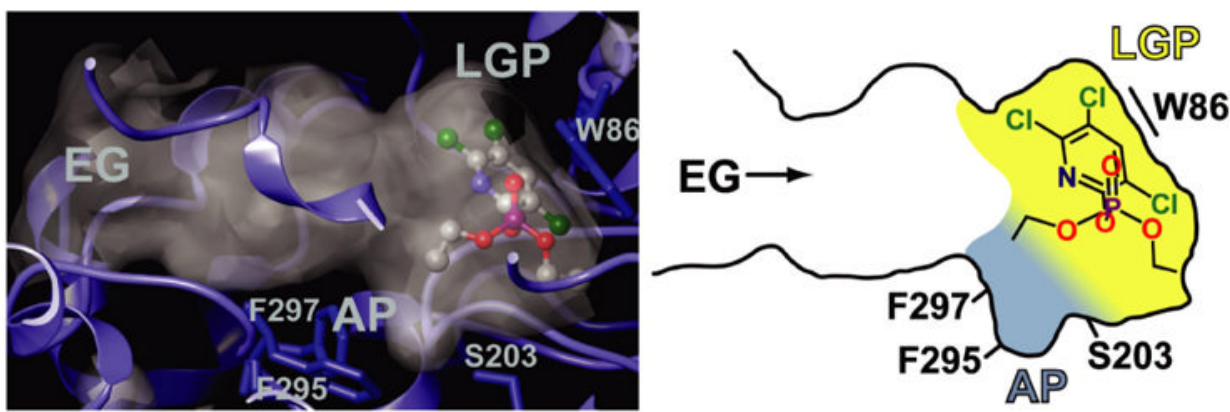

Figure 11.

KIAA1363 and AChE active sites shown as surface visualizations with docking of OP inhibitors 12 and CPO, respectively, defined by structures. The two enzymes are aligned to superimpose their catalytic triads and GXSXG backbones leading to further superimposition of S191, L286 and T289 of KIAA1363 with the spatial equivalent S203, F295 and F297, respectively, of AChE with no equivalent for W86. Differences in OP entry angles and ultimate positioning are dominated by a large EG/AP for KIAA1363 and W86-confined LGP for AChE. On docking CPO at the KIAA1363 active site, the positions of the aryl and phosphate substituents are not changed from those of compound $\mathbf{1 2}$ as shown. 

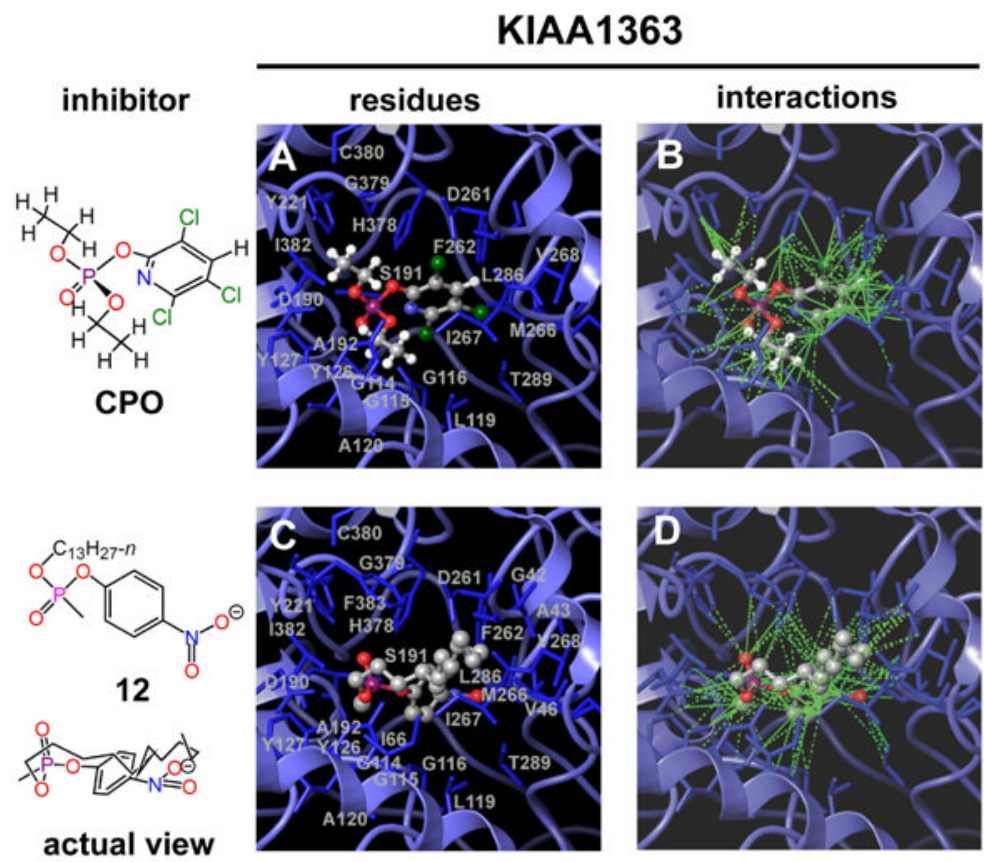

AChE

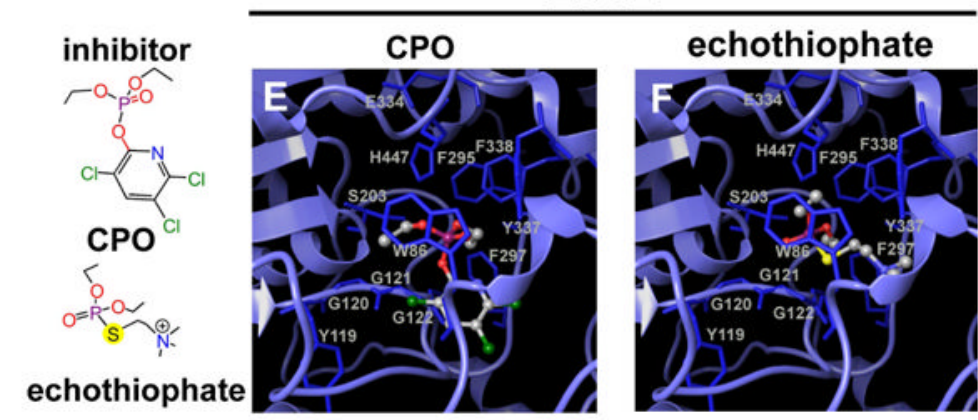

Figure 12.

KIAA1363 and AChE active site residues docked with OP inhibitors. KIAA1363 is viewed looking down into the EG and $\mathrm{AChE}$ from the same angle relative to the GXSXG backbone. Amino acids interacting with CPO and compound $\mathbf{1 2}$ at $1.5 \AA$ are designated in $\mathbf{A}$ and $\mathbf{C}$. Substituent interactions as van der Waals contacts at $1.3 \AA$ are illustrated in green without hydrogen bonding in $\mathbf{B}$ and D. Docking of CPO and echothiophate in AChE is shown in $\mathbf{E}$ and F. 


\section{AChE (slow reactivation)}

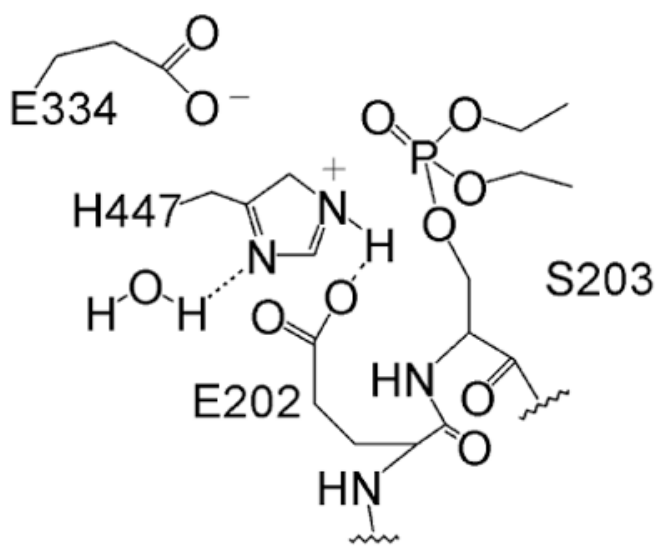

\section{KIAA1363 model structure (rapid reactivation)}

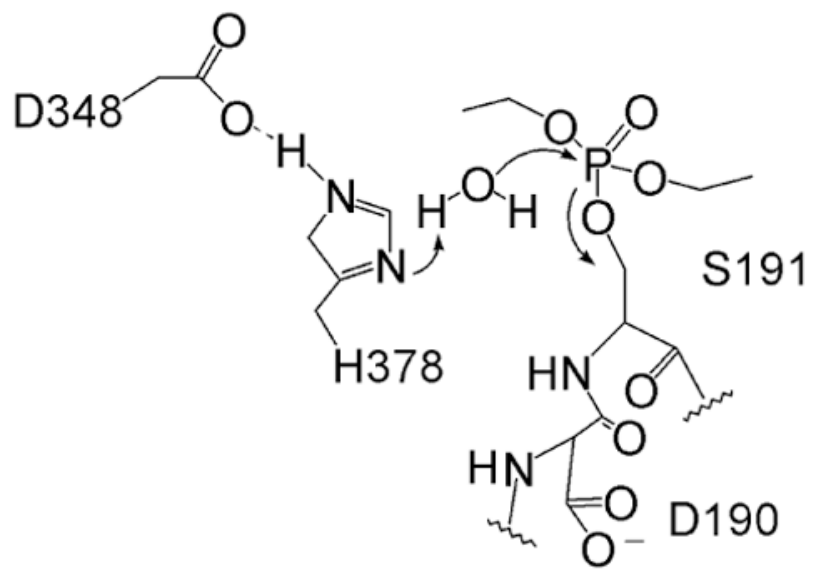

Scheme 1.

Diethylphosphorylated adducts and catalytic triads of mouse AChE and KIAA1363 model structure relative to mechanisms of reactivation. The spatial relationship of substituents is more precisely shown in Figure 10. 


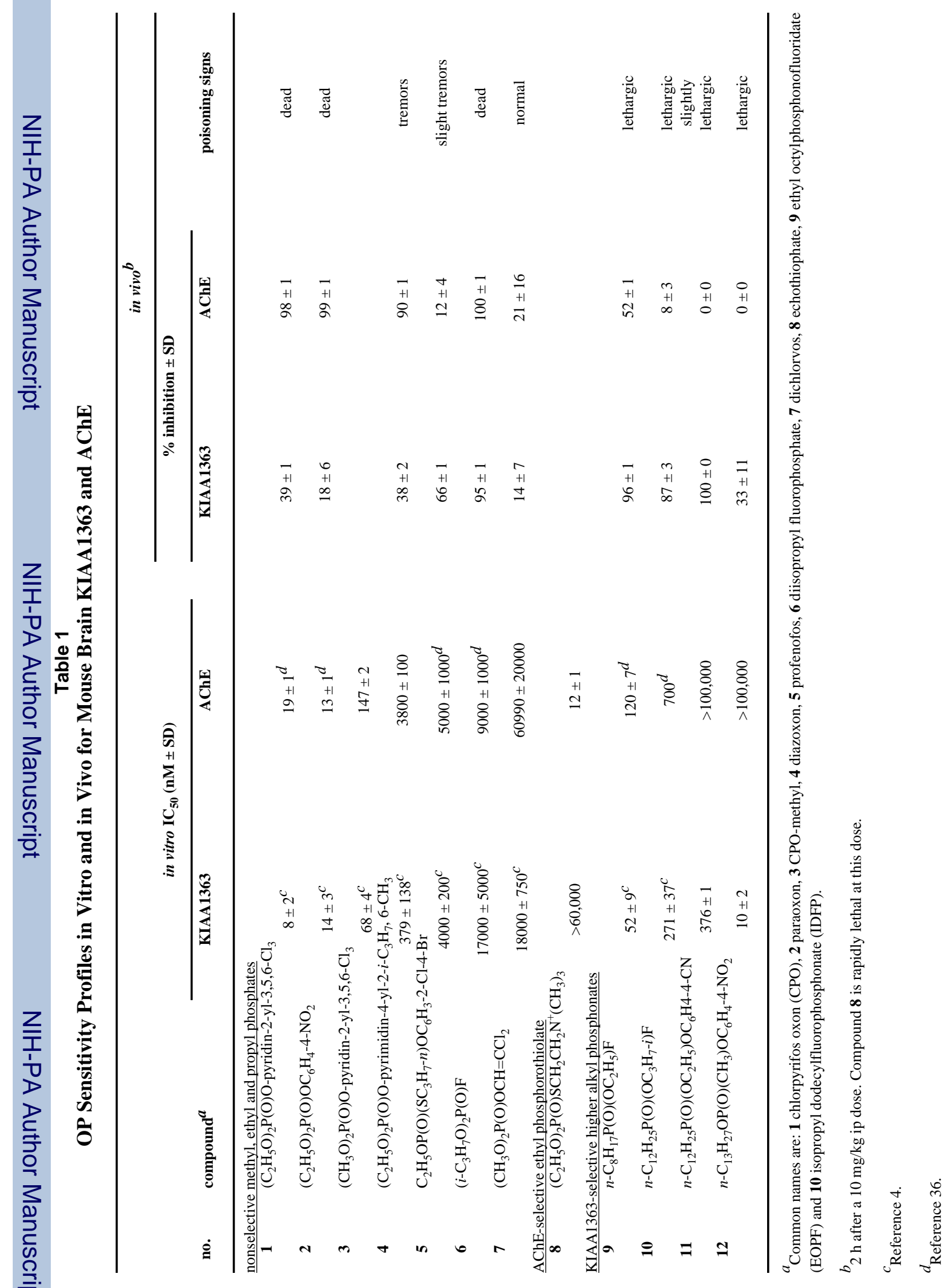

Chem Res Toxicol. Author manuscript; available in PMC 2008 August 12. 
Table 2

Effect of KIAA1363 Gene Deletion on CPO Hydrolysis at $1 \mathrm{nM}$ in Mouse Tissue Membranes and Homogenates

\begin{tabular}{|c|c|c|c|}
\hline \multirow[b]{2}{*}{ tissue $^{a}$} & \multicolumn{3}{|c|}{ percent hydrolysis $^{b}($ mean $\pm S D, n=3)$} \\
\hline & $+/+$ & -/- & ratio \\
\hline brain & $100 \pm 4$ & $8 \pm 2 * * c$ & 13 \\
\hline heart & $96 \pm 6$ & $8 \pm 2 * *$ & 12 \\
\hline spinal cord & $89 \pm 1$ & $24 \pm 2 * * c$ & 4 \\
\hline kidney & $71 \pm 18$ & $28 \pm 7 * *$ & 3 \\
\hline lung & $69 \pm 6$ & $15 \pm 3 * *$ & 5 \\
\hline muscle & $39 \pm 10$ & $11 \pm 2 * *$ & 3 \\
\hline testis & $21 \pm 1$ & $8 \pm 0^{* *}$ & 3 \\
\hline liver & $19 \pm 5$ & $15 \pm 2$ & 1 \\
\hline
\end{tabular}

${ }^{a}$ Membranes except homogenates for spinal cord and muscle.

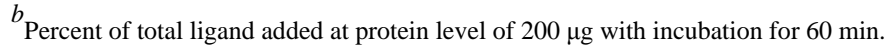

${ }^{c}$ KIAA1363-dependent binding (15 min incubation) and metabolism (60 min incubation) also differ significantly (**) (see supplementary material).

** $\mathrm{p}<0.01$ in unpaired t-test. 
Table 3

Comparison of KIAA1363 and Homologous Serine Hydrolases with AChE

\begin{tabular}{|c|c|c|c|c|}
\hline \multirow[b]{2}{*}{ property } & \multicolumn{3}{|c|}{ KIAA1363 and homologs $a$} & \multirow[b]{2}{*}{$\mathbf{A C h E}$} \\
\hline & KIAA1363 & AADA & AFEST & \\
\hline $\begin{array}{l}\text { Eomorogy } b \\
\text { E-value } b \\
\text { identity (\%) }\end{array}$ & $\begin{array}{c}0 \\
100\end{array}$ & $\begin{array}{c}1 \times 10^{-80} \\
43\end{array}$ & $1 \times 10^{-7}$ & $\begin{array}{l}>1 \\
\mathrm{NA}\end{array}$ \\
\hline \multirow{2}{*}{$\begin{array}{l}\text { amino acids } \\
\text { catalytic triad }\end{array}$} & & & & \\
\hline & $\begin{array}{l}\text { S191 } \\
\text { H378 } \\
\text { D348 }\end{array}$ & $\begin{array}{l}\text { S180 } \\
\text { H371 } \\
\text { D341 }\end{array}$ & $\begin{array}{l}\text { S160 } \\
\text { H285 } \\
\text { D255 }\end{array}$ & $\begin{array}{l}\text { S203 } \\
\text { H447 } \\
\text { E334 }\end{array}$ \\
\hline GXSXG motif & GDSAG & GDSAG & GDSAG & GESAG \\
\hline \multirow[t]{4}{*}{ oxyanion hole } & H 113 & H109 & H86 & Y119 \\
\hline & G 114 & G110 & G87 & G120 \\
\hline & G 115 & G111 & G88 & G121 \\
\hline & G 116 & G112 & G89 & G122 \\
\hline 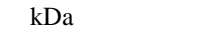 & 45 & 45 & 35 & 65 \\
\hline total amino acids & 408 & 397 & 310 & 583 \\
\hline OP inhibitors & $\mathrm{CPO}$ & FP-rhodamine & paraoxon & $\mathrm{CPO}$ \\
\hline
\end{tabular}

${ }^{a}$ Sequences and relevant data from the following references: KIAA1363, 13; AADA, 39; AFEST, 5; AChE, 40.

${ }^{b}$ Homology relative to KIAA1363. The expectation value (E) threshold is a statistical measure of the number of expected matches in a random database. The lower the number the more likely the match is significant. 